\title{
加味玉女煎이 $\mathrm{db} / \mathrm{db}$ 마우스 糖尿모델에서 脂質代謝와 抗糖尿 效能에 미치는 影響
}

\author{
심부용 ${ }^{1 \#}$, 김동희 ${ }^{1,2^{*}}$ \\ 1 : 대전대학교 난치성 면역질환의 동서생명 의학연구 지역혁신 센터 \\ 2 : 대전대학교 한의과대학 병리학교실
}

\section{Effects of Gamiolnyeo-jeon on Lipid Metabolism and Blood Glucose Level in db/db Mice}

$$
\text { Boo-Yong } \mathrm{Sim}^{1 \#} \text {, Dong-Hee } \mathrm{Kim}^{1,2^{*}}
$$

1 : Traditional and Biomedical Research Center(TBRC), Daejeon University

2 : Dept. of Pathology, College of Oriental Medicine, Daejeon University

\begin{abstract}
Objectives : Abnormal regulation of glucose and impaired lipid metabolism that result from a defective or deficient insulin are the key etiological factor in type 2 diabetes mellitus. The our study investigated the effects of Gamioknyeo-jeon (GO) on blood glucose and lipid metabolism improved by it in $\mathrm{db} / \mathrm{db}$ mice (a murine model of type 2 diabetes mellitus).

Methods : The animals were divided into 3 groups: Normal groups were not-treated C57BL/6 mice; Control groups were treated orally with DW in db/db mice; GO groups were treated orally with GO (200 mg/ kg/day) in $\mathrm{db} / \mathrm{db}$ mice. After mice were treated with GO for 5 weeks, we measured AST, ALT, creatinine, BUN, body weight, food intake, blood glucose, insulin and lipid levels (total cholesterol, HDL cholesterol, and LDL cholesterol and atherogenic index(AI) and cardiac risk factor(CRF).

Results : Serum AST, ALT, creatinine, BUN levels were not changed by GO do not show any toxic effects. GO groups were decreased in body weight, food intake and blood glucose level among compared to Control groups. Also, GO groups were found to have atherogenic Index and cardiac risk factor as well as lipid metabolism improvement (total cholesterol and LDL cholesterol decrease). Finally, GO groups were increased the insulin compared to Normal and control groups.

Conclusions : We suggest that GO may have the control effects of diabetes mellitus by improving blood glucose control and lipid metabolism.
\end{abstract}

Key words : blood glucose, Gamioknyeo-jeon, insulin, lipid metabolism, type 2 diabetic mellitus

\section{서 론}

당뇨병은 인슐린의 의존성/비의존성에 따라 제 1 형과 제 2 형 당뇨병으로 구분할 수 있는데, 제 2형 당뇨병은 전체 당뇨 병의 $90 \%$ 이상을 차지하고 있어 성인당뇨병이라고 불리기도 한다 ${ }^{1)}$. 이러한 제 2형 당뇨병은 보통 비만이 오래 유지 될수 록 발생 가능성이 높으며, 이는 고혈압과 이상지질혈증 (dyslipidaemia) 등의 지질대사와도 밀접하게 연관되어 동맥
경화, 심혈관질환, 신장질환 등의 합병증에 의한 사망률을 증 가 시킨다 ${ }^{1-3)}$.

이러한 당뇨병의 치료는 식이, 운동요법 등을 통해 생활습 관 개선 및 체중감량과 함께 약물요법을 사용하고 있으나, 경 구혈당강하제인 메트포르민 (metformin)은 간에서 당 생산을 감소시키고 말초 인슐린 민감도를 향상시키며 체중을 감소시 키지만 설사, 오심, lactic acidosis 등의 부작용이 있어 효과 적이며 안전성이 입증된 치료제의 개발을 위한 연구가 필요한

\footnotetext{
*Corresponding author : Dong-Hee Kim. Traditional and Biomedical Research Center(TBRC RIC), Daejeon University · Tel : +82-42-280-2623 · Fax : +82-42-280-2624 · E-mail : dhkim@dju.kr

\#First author : Boo-Yong Sim. Traditional and Biomedical Research Center(TBRC RIC), Daejeon University

- Tel : +82-42-280-2828 · Fax : +82-42-280-2624 ·E-mail : boyish3@naver.com

- Received : 17 February 2016 - Revised : 15 March 2016 · Accepted : 21 March 2016
} 
실정이다 ${ }^{4,5)}$.

한의학에서 당뇨병은 胃熱로 인해 多食하게 되고 渴症에 의해 多飲하게 되며, 津液과 肌肉이 마르게 되어 消渴의 범주 에 해당되며 上焦, 中焦, 下焦 등의 병변 부위에 따라 다양한 증상을 나타나게 된다 ${ }^{6,7)}$.

玉女煎은 明代 張의 《景岳全書》 ${ }^{8}$ 에 최초로 수록된 처방 으로 "수 (水)가 허 (虛)하고 화 (火)가 성 (盛)하여 맥 (脈)이 부홍활대 (浮洪滑大)하고 가슴이 답답하고 열이 나며 갈증이 나며 머리와 이가 아픈 등의 증상을 치료한다" 라고 기재된 이래 오랜 임상 경험을 통하여 당뇨병과 고혈압을 비롯하여 광범위하게 응용되는 처방이다.

현재까지 玉女煎의 국내 연구로는 유 ${ }^{9}$ 의 청심연자음과 옥 녀전이 Streptozotocin 투여로 유발된 백서의 고혈당에 미치 는 영향과 조 ${ }^{10)}$ 등의 가미옥녀전이 고혈압백서 (SHR)의 혈압 유관인자 변화에 미치는 영향 등의 연구를 통해 옥녀전이 고 혈당 및 혈압에 효능이 있음을 밝혀내었다. 본 시료인 加味玉 女煎은 여기에 당뇨병의 주된 범주인 消渴의 증세에 활용되는 黃連, 梔子, 玄參을 가미한 처방으로 항당뇨 및 지질대사 기 능에 대해 유효하리라 사료되어 선정하게 되었다.

따라서 본 실험에서는 제 2형 당뇨모델로 알려진 $\mathrm{db} / \mathrm{db}$ 마우스에 加味玉女煎의 경구 투여가 혈당 및 체중, 식이량의 변화, ALT와 AST 등의 간 기능, 인슐린 농도 및 지질대사에 미치는 영향 등에 있어 유의한 결과를 나타내었기에 임상에서 의 활용성을 제고함과 동시에 향후 보다 효과적이고 안전한 한의학적 경구혈당강하제 개발을 위한 기초적 자료를 제공하 고자 하였다.

\section{재료 및 방법}

\section{1. 약재}

본 실험에 사용한 加味玉女煎 (Gamioknyeo-jeon 이하, GO 로 표기)의 구성 약재들은 옴니허브(Korea)에서 구입 하였고, 대전대학교 TBRC-RIC에서 정선 후 사용 하였으며, 그 내용 과 분량 (1첩)은 다음과 같다(Table 1).

Table 1. The prescription of GO

\begin{tabular}{ccc}
\hline Herbal medicine name & Pharmacognostic name & Weight (g) \\
\hline \hline 石 膏 & Gypsum Fibrosum & 12 \\
生地黄 & Rehmanniae Radix Crudus & 12 \\
玄 落 & Scrophulariae Radix & 8 \\
麥門冬 & Liriopis Tuber & 8 \\
川牛膝 & Cyathulae Radix & 6 \\
知 母 & Anemarrhenae Rhizoma & 6 \\
黄 連 & Coptidis Rhizoma & 4 \\
梮 子 & Gardeniae Fructus & 4 \\
\hline Total amount & & \\
\hline
\end{tabular}

\section{2. 동물 및 사료}

본 실험을 위하여 사용된 대조군과 실험군인 $\mathrm{db} / \mathrm{db}$ mouse (5주령, 수컷, 20 27 g)와 정상군으로 사용된 C57BL/6 mouse
(5주령, 수컷, 20 25 g)는 라온바이오 (Korea)에서 구입하여 사용하였다. 실험동물은 2 주간의 안정기를 가지면서 순화를 시켰으며, 안정기 및 실험기간에 모든 실험군에는 일반 사료 (Altromin CO., Germany)를 자유식이 하며 물을 충분히 공 급하였다. 2 주간의 안정기 이후 8 주령부터 동물 실험을 진행 하였다. 동물 사육실의 조건은 conventional system으로 22 $\pm 2{ }^{\circ} \mathrm{C}, 1$ 일 중 12 시간은 $200-300 \mathrm{Lux}$ 로 조명하고, 12 시간 은 모든 빛을 차단하였다. 본 실험은 대전대학교 동물실험윤 리 위원회의 승인 (승인번호 DJUARB2015-034)을 받아 동 물윤리준칙에 의거하여 실험하였다.

\section{3. 시약 및 기기}

사용된 시약은 Rat/Mouse insulin ELISA kit (Biovender., $\mathrm{CZECH)}$ 을 사용하였으며, 기기는 rotary vacuum evaporator (Büchi B-480 Co., Switzerland), freeze dryer (EYELA FDU-540 Co., Japan), ELISA reader (Molecular Devices Co., U.S.A.), 환류 추출기 (Mtops, Korea), 동결 건조기 (IlShinBioBase, Korea), 혈당체크기 (Roche, Switzerland) 등을 사용하였다.

\section{4. 시료 추출}

$\mathrm{GO}$ 2첩 $(120 \mathrm{~g})$ 에 $\mathrm{DW} 1000 \mathrm{~m}$ 을 넣고 3시간 동안 환류 추출 후 여과액을 얻어 rotary vacuum evaporator에서 감 압 농축 하였다. 농축된 용액을 freeze dryer로 동결 건조하 여 분말 $10.7 \mathrm{~g}$ 을 얻었으며, 얻어진 분말은 초저온 냉동고 $\left(-80{ }^{\circ} \mathrm{C}\right)$ 에서 보관하면서 실험에 따라 필요한 농도로 증류수 에 희석하여 사용하였다.

\section{5. 실험 그룹 및 시료 투여}

$\mathrm{db} / \mathrm{db}$ mouse의 기원으로 알려진 $\mathrm{C} 57 \mathrm{BL} / 6$ 마우스를 정상 군으로 분류하였으며, 당뇨 발생 모델로 알려진 $\mathrm{db} / \mathrm{db}$ mouse를 대조군과 실험군으로 그룹당 8 마리씩 나누었다. 실 험동물은 대조군과 실험군의 혈당체크 후 그룹을 배분하였으 며, 실험 시작 시 정상군의 혈당은 $145.3 \pm 17.4 \mathrm{mg} / \mathrm{d}$, 대 조군은 $281.7 \pm 78.9 \mathrm{mg} / \mathrm{dl}$, GO $200 \mathrm{mg} / \mathrm{kg}$ 투여군 (이하, $\mathrm{GO})$ 은 $280.8 \pm 78.7 \mathrm{mg} / \mathrm{dl}$ 이였다. 이때, 혈당의 수치가 낮거 나 높은 모델은 에테르를 이용하여 폐사하였다. 실험 시작 8 주령부터 실험 종료인 12 주령까지 대조군에는 증류수를, 실험 군에는 $\mathrm{GO}$ 를 매일 1 회, 오전 10시에 $200 \mu l$ 씩 경구 투여하 였다. GO 투여량은 성인 체중 $60 \mathrm{~kg}$ 을 기준으로 한 후 마우 스 체중 $30 \mathrm{~g}$ 으로 기준하여 산출하였다.

\section{6. 간 및 신 기능 측정}

혈청 내 간 기능인 Alanine aminotransferase (ALT), Aspartate aminotransferase (AST)와 신 기능인 creatinine, $\mathrm{BUN}$ 활성도를 측정하기 위해 실험 종료 후 심장 천자법을 이용하여 혈액을 채취하였다. 혈액을 30 분간 상온에서 굳힌 뒤 $3,000 \mathrm{rpm}$ 에서 15 분간 원심분리 후 혈청을 분리하여, (주) 옵티팜 (Korea)에 분석 의뢰 하였다. 


\section{7. 혈당 및 식이량, 체중 측정}

혈당 측정은 실험 시작일로부터 실험이 종료되는 주까지 매주 월요일에 측정을 실시하였다. 혈당 측정 3 시간 전부터 절식시킨 후 꼬리 끝을 절단한 뒤 혈당체크기를 이용하여 혈 당을 측정하였으며 식이섭취량 및 체중은 매주 월요일에 $\mathrm{g}$ 단위로 측정하였다.

\section{8. 혈중 내 콜레스테롤 측정}

혈중 내 total cholesterol, HDL-cholesterol, LDLcholesterol 함량을 측정하기 위해 실험 종료 후 심장 천자법 을 이용하여 혈액을 채취하여, 그 혈액을 30 분간 상온에서 굳힌 뒤 $3,000 \mathrm{rpm}$ 에서 15 분간 원심분리 후 혈청을 분리하 여 (주)옵티팜 (Korea)에 분석 의뢰 하였다.

\section{9. 동맥경화지수 $(\mathrm{AI})$ 및 심혈관위험지수 $(\mathrm{CRF})$}

\section{측정}

동맥경화 지수 (Atherogenic Index, AI)는 Fiordaliso의 계산법인 $\mathrm{AI}=([\mathrm{Total}-\mathrm{C}]-[\mathrm{HDL}-\mathrm{C}]) /[\mathrm{HDL}-\mathrm{C}]$ 식을 사용하 여 구하였다. 또한, 심혈관위험지수인 $\mathrm{CRF}$ (Cardiac Risk Factor)는 Rosenfeld의 계산법에 따라 총 콜레스테롤의 양을 $\mathrm{HDL}$ 콜레스테롤의 양으로 나누어 구하였다.

\section{0. 혈청 내 인슐린 측정}

실험 종료 후 ethyl ether로 마취한 상태에서 심장 천자법 을 이용하여 채혈한 다음 $3,000 \mathrm{rpm}$ 에서 15 분간 원심 분리 하여 혈청을 분리한 후, Rat/Mouse Insulin ELISA kit을 이용하여 다음과 같이 측정하였다. 코팅 된 Insulin plate에 washing 완충 용액을 이용하여 세척하고 $100 \mu$ l의 biotin conjugate와 $10 \mu$ l의 standard, 혈청을 넣은 뒤 2 시간 동안 반응시켰다. 반응 후 다시 washing 완충 용액을 이용하여 세 척하고 $100 \mu l$ 의 $\mathrm{HRP}$ conjugate를 넣은 뒤 30 분 동안 반응 시키고 세척작업 후 $100 \mu$ 의 substrate chromogen reagent 를 넣은 후 30 분 동안 반응시켰다. 측정 전 reaction stopper 를 $100 \mu l$ 를 취한 뒤 ELISA reader $450 \mathrm{~nm}$ 에서 흡광도를 측 정하였다.

\section{1. 통계처리}

실험 결과는 실험 결과는 SPSS 11.0 의 unpaired student's $T$-test 및 ANOVA를 사용하여 통계처리 하였으며 $p<0.05$, $p<0.01$ 및 $p<0.001$ 수준에서 유의성을 검정하였다.

\section{결 과}

\section{1. 간 및 신기능에 미치는 영향}

$\mathrm{GO}$ 투여 종료 후에 간 기능 손상마커인 $\mathrm{AST}, \mathrm{ALT}$ 와 신장 기능 손상마커인 creatinine과 $\mathrm{BUN}$ 을 측정한 결과, $\mathrm{AST}$ 는
정상군이 $116.67 \pm 19.70 \mathrm{IU} / \mathrm{L}$ 로 나타난 반면, $\mathrm{GO}$ 는 101.80 $\pm 6.10 \mathrm{IU} / \mathrm{L}$ 로 나타났으며, ALT는 정상군이 $87.14 \pm 7.60$ $\mathrm{IU} / \mathrm{L}$ 로 나타난 반면, $\mathrm{GO}$ 는 $85.42 \pm 2.50 \mathrm{IU} / \mathrm{L}$ 로 나타났다. 또한, Creatinine은 정상군이 $0.40 \pm 0.01 \mathrm{mg} / \mathrm{dl}$ 로 나타난 반면, $\mathrm{GO}$ 는 $0.30 \pm 0.02 \mathrm{mg} / \mathrm{d} \ell$ 로 나타났으며, $\mathrm{BUN}$ 은 정상 군이 $24.29 \pm 3.10 \mathrm{mg} / \mathrm{d} l$ 로 나타난 반면, $\mathrm{GO}$ 는 $21.60 \pm$ $2.80 \mathrm{mg} / \mathrm{d} \ell$ 로 나타났다(Table 2).

Table 2. Effect of GO on the AST, ALT, creatinine and BUN Level in $\mathrm{db} / \mathrm{db}$ Mice

\begin{tabular}{cccc}
\hline & Normal & Control & GO \\
\hline \hline $\operatorname{AST}(/ \ell)$ & $116.67 \pm 19.70$ & $158.86 \pm 25.30$ & $101.80 \pm 6.10$ \\
$\operatorname{ALT}(/ \ell)$ & $87.14 \pm 7.60$ & $92.80 \pm 2.60$ & $85.42 \pm 2.50$ \\
Creatinine (mg/d $)$ & $0.40 \pm 0.01$ & $0.40 \pm 0.01$ & $0.30 \pm 0.02$ \\
$\operatorname{BUN}(\mathrm{mg} / \mathrm{d} \ell)$ & $24.29 \pm 3.10$ & $22.80 \pm 3.00$ & $21.60 \pm 2.80$ \\
\hline
\end{tabular}

\section{2. 체중에 미치는 영향}

체중 증가에 미치는 영향을 측정한 결과, 대조군은 실험 시작 시 $39.38 \pm 1.05 \mathrm{~g}$ 에서 종료 후 $49.25 \pm 1.57 \mathrm{~g}$ 로 $9.87 \mathrm{~g}$ 의 증가를 나타낸 반면, $\mathrm{GO}$ 는 실험 시작 시 $41.93 \pm 1.84 \mathrm{~g}$ 에서 종료 후 $46.08 \pm 3.01 \mathrm{~g}$ 로 $4.15 \mathrm{~g}$ 의 증가가 나타나 대 조군에 비해 체중의 증가가 적게 나타났다(Table 3).

Table 3. Effect of GO on Body Weight Gain in $\mathrm{db} / \mathrm{db}$ Mice

\begin{tabular}{cccc}
\hline & Normal & Control & GO \\
\hline \hline Initial body weght $(\mathrm{g})$ & $20.40 \pm 0.45$ & $39.38 \pm 1.05$ & $41.93 \pm 1.84$ \\
Final body weight $(\mathrm{g})$ & $25.51 \pm 0.69$ & $49.25 \pm 1.57$ & $46.08 \pm 3.01$ \\
Weight gain $(\mathrm{g})$ & +5.11 & +9.87 & +4.15 \\
\hline
\end{tabular}

\section{3. 식이량에 미치는 영향}

식이량 섭취에 미치는 영향을 측정한 결과, 대조군은 실험 시작 8주령에서 $244 \mathrm{~g}$, 9주령에서 $261 \mathrm{~g}, 10$ 주령에서 $213 \mathrm{~g}$, 11 주령에서는 $255 \mathrm{~g}$, 실험 종료 12 주령에서는 $235 \mathrm{~g}$ 로 나타난 반면, $\mathrm{GO}$ 는 실험 시작 8주령에서 $231 \mathrm{~g}, 9$ 주령에서 $175 \mathrm{~g}$, 10 주령에서 $217 \mathrm{~g}, 11$ 주령에서는 $124 \mathrm{~g}$, 실험 종료 12 주령 에서는 $196 \mathrm{~g}$ 으로 나타나, $\mathrm{GO}$ 는 대조군에 비해 식이량 감소 가 나타났다(Fig. 1).

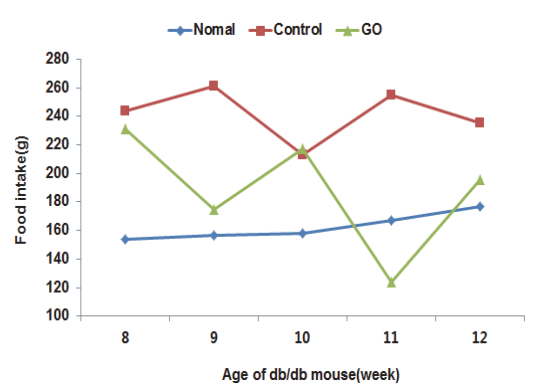

Fig. 1. Change in the food intakes of the exper imental groups. The results were expressed as mean \pm S.D. $(n=8)$. Normal : Non treated C57BL/6 mice

Control $: \mathrm{db} / \mathrm{db}$ mice group were treated orally with $\mathrm{DW}$ GO : db/db mice group were treated orally with $G O 200 \mathrm{mg} / \mathrm{kg} /$ day 


\section{4. 혈당변화에 미치는 영향}

혈당 변화에 미치는 영향을 측정한 결과, 대조군은 실험 시 작 8 주령에서 $281.7 \pm 78.9 \mathrm{mg} / \mathrm{d} \ell$, 9주령에서 $241.7 \pm 35.1$ $\mathrm{mg} / \mathrm{d} \ell, 10$ 주령에서 $376.3 \pm 70.1 \mathrm{mg} / \mathrm{d} \ell, 11$ 주령에서는 396.3 $\pm 58.8 \mathrm{mg} / \mathrm{d} \ell$, 실험 종료 12 주령에서는 $600.0 \pm 104.1 \mathrm{mg} / \mathrm{d} \ell$ 로 나타나 $318.3 \mathrm{mg} / \mathrm{d} l$ 의 증가가 나타난 반면, $\mathrm{GO}$ 는 실험 시작 8 주령에서 $280.8 \pm 78.8 \mathrm{mg} / \mathrm{d} \ell$, 9주령에서 $202.7 \pm$ $25.4 \mathrm{mg} / \mathrm{d} \ell, 10$ 주령에서 $312.8 \pm 52.8 \mathrm{mg} / \mathrm{d} \ell, 11$ 주령에서는 $383.3 \pm 31.3 \mathrm{mg} / \mathrm{dl}$, 실험 종료 12 주령에서는 $482.7 \pm 66.7$ $\mathrm{mg} / \mathrm{d} \ell$ 로 나타나 $201.9 \mathrm{mg} / \mathrm{d} \ell$ 의 증가가 나타나 대조군에 비해 유의성 있는 $\left(^{*}: p<0.05\right)$ 혈당 변화를 나타내었다(Fig. 2).

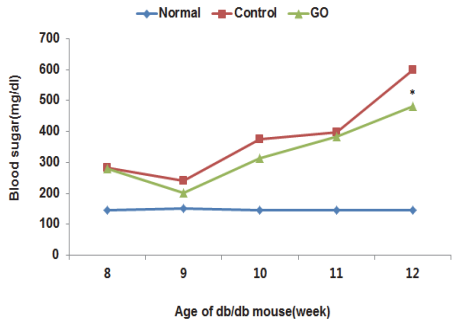

Fig. 2. Effect of GO on change of blood sugar in $\mathrm{db} / \mathrm{db}$ mice. The results were expressed as mean \pm S.D. (Significance of results, : $p<0.05$ compare to control $)(\mathrm{n}=8)$.

Normal : Non treated C57BL/6 mice

Control : $\mathrm{db} / \mathrm{db}$ mice group were treated orally with DW

GO : db/db mice group were treated orally with GO $200 \mathrm{mg} / \mathrm{kg} /$ day

\section{5. 콜레스테롤에 미치는 영향}

$\mathrm{GO}$ 투여 종료 후에 혈청 내 total cholesterol과 HDLcholesterol, $\mathrm{LDL}$-cholesterol을 측정한 결과, total cholesterol 은 대조군이 $176.0 \pm 6.4 \mathrm{mg} / \mathrm{d} \ell$ 을 나타난 반면, $\mathrm{GO}$ 는 108.0 $\pm 3.1 \mathrm{mg} / \mathrm{d} l$ 으로 나타났으며(Fig. $3 \mathrm{~A}$ ), HDL-cholesterol은 대조군이 $100.0 \pm 4.0 \mathrm{mg} / \mathrm{d} \ell$ 을 나타난 반면, GO는 $100.0 \pm$ $4.5 \mathrm{mg} / \mathrm{d} \ell$ 으로 나타났다(Fig. 3B). 또한, $\mathrm{LDL}-$ cholesterol은 대조군이 $8.7 \pm 0.7 \mathrm{mg} / \mathrm{d} \ell$ 을 나타난 반면, $\mathrm{GO}$ 는 $6.1 \pm 0.5$ $\mathrm{mg} / \mathrm{d} l$ 로 감소가 나타나(Fig. $3 \mathrm{C}$ ), 대조군에 비해 total cholesterol과 LDL-cholesterol은 유의성 있는 ${ }^{* * * *}: p<$ $0.001, ": p<0.05)$ 감소가 나타났다(Fig. 3A, 3C).

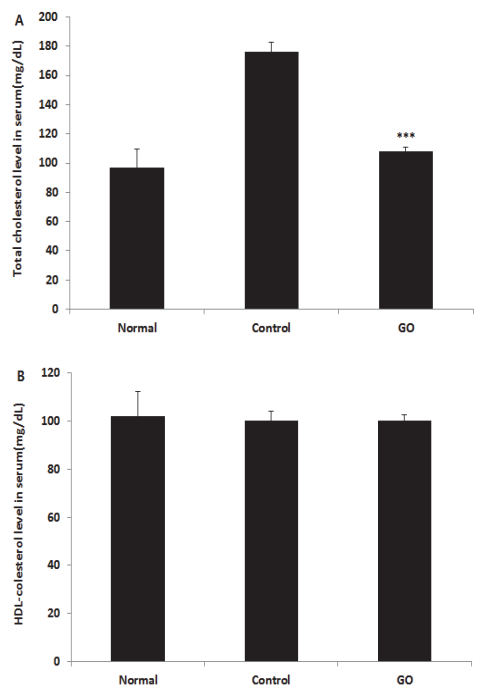

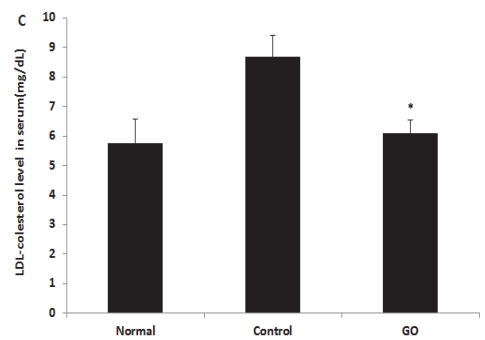

Fig. 3. Effect of GO on total cholesterol (A), HDL-cholesterol (B) and $\mathrm{LDL}$-cholesterol (C) level of serum in $\mathrm{db} / \mathrm{db}$ mice The results were expressed as mean \pm S.D. (Significance of results, ${ }^{* * *}: p<$ 0.001 compare to control) $(n=8)$.

Normal : Non treated C57BL/6 mice

Control $: \mathrm{db} / \mathrm{db}$ mice group were treated orally with DW GO : db/db mice group were treated orally with GO $200 \mathrm{mg} / \mathrm{kg} /$ day

\section{6. $\mathrm{AI}$ 및 $\mathrm{CRF}$ 에 미치는 영향}

동맥경화지수를 측정한 결과, 대조군이 $4.50 \pm 0.08$ 로 나 타난 반면, $\mathrm{GO}$ 는 $0.80 \pm 0.05$ 로 적게 나타나 유의성 있는 $\left.{ }^{* * *}: p<0.01\right)$ 감소가 나타났다. 또한, 심혈관 위험지수를 측 정한 결과, 대조군이 $1.45 \pm 0.02$ 로 나타난 반면, $\mathrm{GO}$ 는 $1.08 \pm 0.01$ 로 적게 나타났다(Table 4).

Table 4. Al and CRF of Serum in $\mathrm{db} / \mathrm{db}$ Mice Containing GO

\begin{tabular}{cccc}
\hline & Normal & Control & GO \\
\hline \hline $\mathrm{AI}$ & $-0.05 \pm 0.04$ & $4.50 \pm 0.08$ & $0.80 \pm 0.05^{* * *}$ \\
$\mathrm{CRF}$ & $0.71 \pm 0.03$ & $1.45 \pm 0.02$ & $1.08 \pm 0.01$ \\
\hline
\end{tabular}

\section{Insulin에 미치는 영향}

$\mathrm{GO}$ 투여 종료 후에 insulin 함량을 측정한 결과, 대조군 이 $21.0 \pm 0.9 \mathrm{uU} / \mathrm{m} \ell$ 을 나타난 반면, $\mathrm{GO}$ 는 $46.3 \pm 2.7 \mathrm{uU} /$ $\mathrm{m} l$ 으로 나타나 유의성 있는 $\left(^{* *}: p<0.01\right)$ 증가를 나타내었다 (Fig. 4).

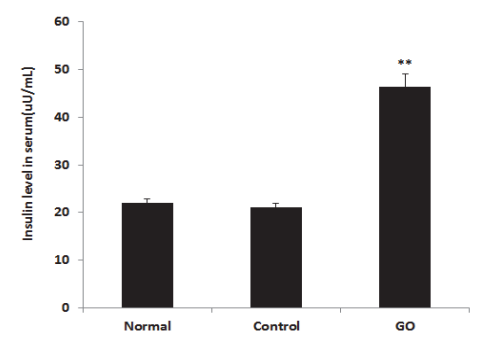

Fig. 4. Effect of GO on insulin level of serum in $\mathrm{db} / \mathrm{db}$ mice. The results were expressed as mean \pm S.D. (Significance of results, $: p<0.01$ compare to control $)(\mathrm{n}=8)$. Normal : Non treated C57BL/6 mice

Control : $\mathrm{db} / \mathrm{db}$ mice group were treated orally with DW

GO : db/db mice group were treated orally with GO $200 \mathrm{mg} / \mathrm{kg} /$ day

\section{고 찰}

당뇨병은 인슐린 생성 분비장애와 말초조직에 대한 인슐린 저항에 의해 탄수화물, 지방 및 단백질 등의 생체 내 대사 기 능의 이상을 초래하는 만성적인 대사성 질환이다 ${ }^{11)}$. 당뇨병의 특징은 혈중 중성지방 증가와 $\mathrm{HDL}$-콜레스테롤의 감소이며, 
이 같은 지질대사 이상의 발생으로 인하여 고혈당, 고지혈증 등 여러 합병증을 동반한다 ${ }^{12,13)}$.

현재 제 1 형 당뇨병에 대한 치료는 인슐린 투여가 아직은 가장 주된 치료법이며, 그밖에 췌장이식이 시도되고 있다 ${ }^{14,15)}$. 또한, 당뇨병의 대다수를 차지하는 제 2 형 당뇨병에 대 한 기존의 치료법은 식사 및 운동요법, 여러 의약품들이 사용 되고 있지만 치료의 한계와 부작용으로 인해 안전하고 효과적 인 치료를 위해 한의학계에서도 연구가 진행되고 있으나, 임 상 및 실험적 연구 결과를 바탕으로 한 기초자료가 많지 않은 실정이다. 따라서 대증치료라는 한계성과 부작용에 대한 보완 적인 $\mathrm{EBM}$ 기초 자료가 필요한 실정이다.

$\mathrm{db} / \mathrm{db}$ 마우스 $(\mathrm{C} 57 \mathrm{BL} / \mathrm{KsJ})$ 는 시상하부에 위치하는 비만 호르몬 (leptin)의 수용체인 $\mathrm{Ob}-\mathrm{Ra}$ 가 돌연변이되어 시상하부 에서 leptin의 신호전달과정에 결함이 생겨 과도한 먹이 섭 취, 지방 축적이 일어나 제 2 형 당뇨와 유사한 형태의 비만 증, 고혈당 등의 특징을 나타내는 동물로 알려져 있다 ${ }^{15,16)}$ 따라서 본 연구에서는 $\mathrm{db} / \mathrm{db}$ 마우스를 활용하여 가미옥녀전 (GO)의 경구 투여가 체중, 식이량, 혈당 등의 변화 및 콜레 스테롤, 동맥경화지수, 심혈관 위험지수, 인슐린에 미치는 영 향 등을 확인하였다.

우선, 실험 종료 후 혈액으로 ALT, AST, BUN, creatinine 수치에 미치는 영향을 조사한 결과, 정상군 범위에서 큰 차 이를 나타내지 않아 $\mathrm{GO}$ 는 간과 신기능에 영향이 없이 안전 한 것으로 나타났다. 이 같은 결과만으로 안전성을 확보하기 는 어렵지만, 이미 복용 후 평가된 in-vivo 실험 결과 측면 에서는 안전하다고 평가하였다.

일정수준 이상으로 혈당이 높아지면 걸러져나가는 포도당 의 일부가 재흡수되지 못하고 소변이 배출되는데, 이렇게 빠 져나가는 포도당은 체내수분을 같이 끌고 체외로 배출되기 때 문에 소변량이 증가하여 체내수분의 손실이 많아지고 이를 보 충하기 위해 음수량도 증가하게 된다 ${ }^{17)}$. 그리고 혈중 포도당 함량은 높으나 이를 세포 내에서 이용하지 못하여 에너지 부 족현상을 초래하면 이로 인해 식이섭취량이 증가한다 ${ }^{18)}$. 이는 한의학에서 말하는 多飲, 多食, 多尿에 해당되는 것으로 당뇨 병의 대표적 증상이다. 본 연구에서 $\mathrm{GO}$ 의 경구 투여 시작부 터 종료까지 매주차별로 체중, 식이량, 혈당을 확인한 결과, $\mathrm{GO}$ 는 대조군에 비해 체중 및 식이량, 혈당을 모두 현저히 감 소시키는 것을 확인하였다. 이는 $\mathrm{GO}$ 가 혈당 조절을 통해 식 이량을 감소시키고 이로 인해 체중의 감소가 나타난 것으로 당뇨의 주된 생리적 변화에 있어 효능이 있음을 객관적으로 증명해주고 있다.

당뇨병환자의 이상지질혈증에 대한 가장 큰 특징은 $\mathrm{HDL}-$ cholesterol의 저하와 작고 밀도 높은 (small dense) LDLcholesterol의 증가로 요약된다 ${ }^{19-23)}$. HDL-cholesterol은 동 맥으로부터 콜레스테롤을 간으로 운반해주는 지질단백질로서 혈액 내 증가는 혈액 및 조직으로부터 간에 이르는 콜레스테 롤 운반능력을 높여 줌으로써 콜레스테롤의 역수송에 의하여 혈액 콜레스테롤을 제거하여 동맥경화와 혈관 장애 개선에 효 과가 있다. 반면 LDL-cholesterol는 동맥 내 콜레스테롤 축 적에 관계하는 가장 주요한 지질 운반체로서 cholesterol ester를 간에서 혈액 및 신체 내 여러 부위의 말초 조직 세포 속으로 수송해 준다. 체내 항상성에 의해 균형을 이루고 있는 체내 지질 균형이 깨어지면 $\mathrm{LDL}-$ cholesterol는 증가하고,
$\mathrm{HDL}$-cholesterol는 감소하여 동맥경화증, 고혈압 및 심혈관 계 질환을 유발한다 ${ }^{24)}$. 본 연구에서 $\mathrm{GO}$ 가 콜레스테롤과 동맥 경화지수 및 심혈관 위험지수에 미치는 영향을 확인한 결과, $\mathrm{GO}$ 는 대조군에 비하여 콜레스테롤의 유의성 있는 감소와 $\mathrm{LDL}-$ cholesterol의 감소에 따른 동맥경화지수와 심혈관 위 험지수를 감소시켰다. 이와 같은 결과는 $\mathrm{GO}$ 가 당뇨병의 이상 지질혈증을 개선하고 더 나아가 심혈관질환의 주요 위험인자 인 이상지질혈증을 개선함으로써 심혈관질환을 예방하고 개선 할 수 있음을 시사한다.

Insulin은 췌장의 $\beta$-세포에서 분비되는 호르몬으로, 혈액 속의 당분 (포도당)을 몸속의 여러 장기에서 이용할 수 있도 록 하여 혈당을 일정하게 유지하는 역할을 할 뿐만 아니라 우 리가 섭취하는 주요 영양소인 지질과 단백질 대사에도 중요한 역할을 수행한다 ${ }^{25)}$. 이와 같은 인슐린은 제 2 형 당뇨환자에게 서 인슐린의 생산 장애와 $\beta$-세포의 파괴에 의한 인슐린 분비 장애와 인슐린의 감수성 변화 및 작용 장애에 의한 인슐린 저 항성이 혈당 상승의 원인으로 알려져 있다 ${ }^{1)}$. 송 등의 한국인 제 2 형 당뇨병환자의 인슐린분비능과 인슐린저항성에 따른 임 상적 특성 연구에 의하면 제 2 형 당뇨병환자군의 $46.1 \%$ 에서 인슐린 분비장애를 보인다는 결과를 제시하였다 ${ }^{26)}$. 본 연구에 서 $\mathrm{GO}$ 는 대조군에 비해 insulin의 함량을 유의성 있게 증가 시켜 혈당 감소 결과와 부합되었다. 이와 같은 결과는 $\mathrm{GO}$ 가 인슐린 분비장애에 의한 제 2 형 당뇨병 환자들의 치료제로써의 활용과 동시에 제 1 형 당뇨에도 가능성이 있을 것이라 사료된 다. 다만, 제 1 형 당뇨는 인슐린 의존성 질환이기에 기전에 차 이가 있어 추후 심도있는 연구를 통해 확인해 보고자 한다.

이상의 결과를 종합해 볼 때, $\mathrm{GO}$ 는 제 2 형 당뇨 모델인 $\mathrm{db} / \mathrm{db}$ 마우스를 통해 안전하고 당뇨의 대표적 증상인 혈당과 식이량, 체중을 감소시키며 콜레스테롤 개선 효능을 통해 동 맥경화지수와 심혈관 위험지수를 낮추며 인슐린을 증가시키는 것을 입증함으로써 제 2 형 당뇨병 및 당뇨에 의한 합병증 개 선에 효과적인 처방임을 입증하였다. 따라서 향 후 개별약재 에 대한 효능과 약재간의 상승작용에 대한 보다 심도있는 연 구가 필요할 것으로 보이며, 加味玉女煎이 원방인 玉女煎 보 다 제 2 형 당뇨에 대해 더 우수한 효능이 있는지에 대한 구체 적인 연구가 필요할 것으로 사료된다.

\section{결 론}

본 연구에서는 $\mathrm{db} / \mathrm{db}$ 마우스에서 加味玉女煎 (GO)의 지질 대사 개선 및 항당뇨 효능을 객관적으로 검증하기 위하여, 간 및 신 기능, 체중 및 식이량, 혈당 등의 변화, 콜레스테롤 및 동맥경화지수, 심혈관 위험지수, 인슐린에 미치는 영향을 확 인한 결과 다음과 같은 결론을 얻었다.

1. $\mathrm{GO}$ 투여군은 $\mathrm{db} / \mathrm{db}$ 마우스의 혈액 내 ALT, AST, creatinine, BUN 수치에서 모두 정상 범위에서 큰 차 이를 나타내지 않아 체내 독성을 유발하지 않았다.

2. GO 투여군은 체중, 식이량, 혈당 등이 대조군에 비해 감소하였다. 
3. $\mathrm{GO}$ 투여군은 총 콜레스테롤 및 $\mathrm{LDL}$ 콜레스테롤이 대 조군에 비해 감소하였으며 $\mathrm{HDL}$ 콜레스테롤은 차이가 나타나지 않았다.

4. GO 투여군은 동맥경화지수 및 심혈관위험 지수가 대조 군에 비해 적게 나타났다.

5. GO 투여군은 정상군과 대조군에 비해 인슐린 함량을 증가시켰다.

이상의 결과들로 보아 加味玉女煎은 제 2 형 당뇨모델인 $\mathrm{db} / \mathrm{db}$ 마우스에서 지질대사와 항당뇨 및 주된 증상에 대한 감소 효 능이 실험적으로 규명되었다. 보다 구체적인 치료 기전은 향 후 보다 심도있는 연구를 통하여 보완되어야 할 것으로 보이 나 이와 같은 결과는 加味玉女煎이 제 2 형 당뇨병의 치료제로 서 우수한 효과가 있으며, 추후 임상적으로 엄격한 기준을 충 족한 연구가 필요할 것으로 사료된다.

\section{감사의 글}

본 연구는 산업통상자원부 지정 대전대학교 난치성 면역질환 의 동서생명 의학연구 지역혁신 센터의 지원에 의한 것입니다.

\section{References}

1. Korean Diabetes Association. Handbook of Diabetes. Seoul : E-PUBRIC. 2006 : 2-4.

2. Ceska R, Vrablik M, Sucharda P. Dyslipidemia and obesity 2011. Similarities and differences. Vnitr Lek. 2011 ; 57(3) : 248-53.

3. Mandavia CH, Aroor AR, Demarco VG, Sowers JR. Molecular and metabolic mechanisms of cardiac dysfunction in diabetes. Life Sci. 2013 ; 92(11) : 601-8.

4. Norman L. Manual of endocrinology and metalolism. Seoul : Hanmibooks. 2010 : 665-6.

5. Bray GA. Office management of obesity. Seoul : Hanmibooks. 2005 : 242-6.

6. Hong WS. Hwang-Je-Nae-Gyeong-So-Moon. Seoul : Publisher of Oriental medicine. 1981 : 18, 138, $145,163,179,180,238,249,257,263,269,274$, 297, 299, 301, 304

7. Oh TW, Kang SY, Park YK. Histological analysis of five organs in streptozotocin -induced diabetic rats. Kor J Herbol. 2013 ; 28(6) : 39-45.

8. Jang GB. Kyungakjeonsuh. Seoul : Bubinbooks. 2007 : 972.

9. Yoo DH. Effects of silbieum and lieumjeon on rats with acute renal failure induced by gentamicin sulfate. Kyunghee University. 1990.

10. Jo CH, An JJ, Jo HK, Yoo HY, Seol IC, Kim YS,
The Effect of Gamioknyeo-jeon on Spontaneously Hypertensive Rats. Korean J Orient Int Med. 2010 ; 31(1) : 142-52.

11. Han HK, Yoon SJ, Kim GH. Effects of compositae plants on plasma glucose and lipid level in streptozotocin induced diabetic rats. J Korean Soc Food Sci. 2009 ; 38(6) : 674-82.

12. Han YK, Park YK. Effect of atractylodis rhizoma alba water extract on streptozotocin-induced diabetes in rats. Kor J Herbol. 2011 ; 26(4) : 23-30.

13. Han HK, Je HS, Kim GH. Effects of cirsium japonicum powder on plasma glucose and lipid level in streptozotocin induced diabetic rats. Korean J Food Sci Technol. 2010 ; 42(3) : 343-9.

14. Shah B, Sha D, Xie D, Mohler ER 3rd, Berger JS. The relationship between diabetes, metabolic syndrome, and platelet activity as measured by mean platelet volume: the national health and nutrition examination survey. Diabetes Care. 2012 ; 35(5) : 1074-8.

15. Lee YJ, Lee YJ, Yoon JJ, Lee SM, Kim HY, Shin SH, Kang DG, Lee HS. Anti-diabetic and AntiInflammatory Effects of Water Extract of Ligustrum japonicum Leaves in db/db Mouse. Kor J Herbol. 2012 ; 27(6) : 107-14.

16. Reaven GM, Bernstein R, Davis B, Olefsky JM. Nonketotic diabetes mellitus: insulin deficiency or insulin resistance? Am J Med. 1976 ; 60(1) : 80-8.

17. Yoon JA, Son YS. Effects of fruits and stems of opunita ficus-indica on blood glucose and lipid metabolism in streptozotocin-induced diabetic rats. J Korean Soc Food Sci Nutr. 2009 ; 38(2) : $146-53$

18. Han YK, Park YK. The comparisons of Lycii Radicis Cortex and Corni Fructus water extract effects on streptozotocin -induced diabetes in rats. Kor J Herbol. 2013 ; 28(6) : 71-7.

19. Korean Diabetes Association. Diabetes. 3rd ed. Seoul : Korean Diabetes Association. 2005 : 443-50.

20. Goldberg IJ. Clinical review 124 : Diabetic dyslipidemia : causes and consequences. J Clin Endocrinol Metab. 2001 ; 86(3) : 965-71.

21. American Diabetes Association. Standards of medical care in diabetes-2010. Diabetes Care. 2010 ; 33(1) : S11-61.

22. Syvänne M, Taskinen MR. Lipids and lipoproteins as coronary risk factors in non-insulin-dependent diabetes mellitus. Lancet. 1997 ; 350(1) : SI20-3.

23. Kim EL, Kim CS, Lee HY, Lee HR, Kim EY, Yoon $\mathrm{MC}$, Shin SS. Mountain cultivated ginseng water boiled extract decreases blood glucose level and improves lipid metabolism in male $\mathrm{db} / \mathrm{db}$ mice. Kor J Herbol. 2012 ; 27(2) : 69-75. 
24. Rosenfeld L. Lipoprotein analysis. Arch pathol Lab. $1989 ; 113(10): 1101-10$.

25. Lee YM. Effects of Barley Leaf Powder on Lipid Metabolism in Rats and its Antidiabetic Activity. Chosun University. 2011.

26. Song KE, Kim DJ, Park JW, Cho HK, Lee KW, Huh KB. Clinical Characteristics of Korean Type 2 Diabetic Patients According to Insulin Secretion and Insulin Resistance. Diabetes Metabolism J. 2007 ; 31(2) : 123-9. 